\title{
GAMBARAN KESINTASAN 3 TAHUN PASIEN HIV/AIDS BERDASARKAN KETIDAKPATUHAN BEROBAT DI RUMAH SAKIT PENYAKIT INFEKSI PROF. DR. SULIANTI SAROSO TAHUN 2010-2012
}

Hendra Dhermawan Sitanggang ${ }^{1}$, Tri Yunis Miko Wahyono ${ }^{2}$, Adria Rusli ${ }^{3}$, Mondastri Korib Sudaryo ${ }^{4}$

${ }^{1}$ Departemen Epidemiologi, Fakultas Kesehatan Masyarakat, Universitas Indonesia, ${ }^{2}$ Departemen Epidemiologi, Fakultas Kesehatan Masyarakat, Universitas Indonesia, ${ }^{3}$ Rumah Sakit Penyakit Infeksi

Prof. Dr. Sulianti Sarosos Jakarta, ${ }^{4}$ Departemen Epidemiologi, Fakultas Kesehatan Masyarakat, Universitas Indonesia

\begin{abstract}
Abstrak : Penelitian ini bertujuan untuk mengetahui gambaran kesintasan 3 tahun pasien HIV/AIDS berdasarkan ketidakpatuhan berobat. Penelitian ini menggunakan desain kohort retrospektif di RSPI Prof. Dr. Sulianti Saroso tahun 2010-2012. Probabilitas survival kumulatif pasien HIV/AIDS di RSPI Prof dr. Sulianti Saroso pada tahun kedua (bulan ke-24) adalah 95,6\% dan tahun ketiga (bulan ke-36) adalah 91\%. Probabilitas kesintasan 3 tahun pasien yang patuh minum obat $(97,6 \%)$ lebih tinggi dibandingkan pada yang tidak patuh minum obat $(83,1 \%)$. Berdasarkan ketidakpatuhan terhadap janji ambil obat, probabilitas kesintasan 3 tahun pasien yang patuh ambil obat $(93,8 \%)$ juga lebih tinggi dibanding yang tidak patuh $(88,1 \%)$. Ketidakpatuhan minum obat dapat menyebabkan kegagalan terhadap penekanan replikasi virus HIV, sehingga meningkatkan kemungkinan bermutasinya virus HIV yang dapat menyebabkan resisten terhadap obat dan akhirnya dapat meningkatkan risiko kematian. Ketidakpatuhan terhadap janji ambil obat pada 1 tahun pertama juga diasumsikan juga akan menunjukkan ketidakpatuhan terhadap janji ambil obat selanjutnya dan menunjukkan ketidakpatuhan minum obat, sehingga meningkatkan risiko kematian. Perlu dilakuakan monitoring cakupan kepatuhan minum obat pasien HIV/AIDS secara berkala sebagai kewaspadaan dini terhadap risiko kematian pasien HIV/AIDS.
\end{abstract}

Kata Kunci : ketidakpatuhan minum obat, janji ambil obat, kohort retrospektif

\section{DESCRIPTION OF 3-YEARS SURVIVAL PATIENT WITH HIV/AIDS BASED ON NON-COMPLIANCE MEDICATION AT THE INFECTIOUS DISEASES HOSPITAL PROF. DR. SULIANTI SAROSO IN 2010-2012}

\begin{abstract}
The objective of this study was to described 3-years survival of patients with HIV/AIDS based on non-compliance medication. This study used a retrospective cohort design at RSPI Prof. Dr. Sulianti Saroso in 2010-2012. The cumulative survival probability of patients with HIV/AIDS at RSPI Prof. dr. Sulianti Saroso in the second year (24th month) was $95.6 \%$ and the third year (in the 36th) was $91 \%$. Probability 3-years survival patients with HIV/AIDS whom were adherence $(97,6 \%)$ was higher than non-adherence $(83,1 \%)$. Based on incompliance to appointment of taking drugs, probability 3-years survival among patient whom were compliance $(93,8 \%)$ was also higher than incompliance $(88,1 \%)$. Nonadherence to ART may caused a failure of the suppression on HIV viral, thus increase the possibility of HIV virus mutations that can lead to drug-resistant and ultimately increase the risk of death. Poor compliance to appointments of taking drugs in the first year also assumed the poor adherence of the next assignment to take drugs in the further, and show disobedience to ART, so it will increase the risk of death. Need to monitor coverage of medication adherence of patients with HIV/AIDS in a regular basis as the early warning on the risk of death among patients with HIV/AIDS.
\end{abstract}

Keyword : non-adherence to ART, appointment keeping, retrospective cohort

Korespondensi :

Hendra Dhermawan Sitanggang

Departemen Epidemiologi, Gd.A Lt.1, Fakultas

Kesehatan Masyarakat, Universitas Indonesia, HP : 081361918000

Email : hendra_sitanggang88@yahoo.com

\section{PENDAHULUAN}

Salah satu program penanggulangan AIDS di Indonesia adalah pemberian terapi Antiretroviral (ARV) ${ }^{1}$. Antiretroviral (ARV) merupakan obat yang digunakan dalam terapi ODHA. untuk mencegah 
replikasi virus HIV yang secara bertahap menurunkan jumlah virus dalam darah. Tujuan terapi ARV adalah untuk meningkatkan kualitas hidup ODHA dan menurunkan angka kesakitan dan kematian. Terapi ARV juga dapat mencegah penularan HIV. Penemuan obat ARV pada tahun 1996 mendorong suatu revolusi dalam perawatan ODHA, baik di negara dengan pendapatan tinggi maupun di negara pendapatan menengah dan rendah. Secara dramatis terapi ARV menurunkan angka kematian dan kesakitan, meningkatkan kualitas hidup ODHA, dan meningkatkan harapan masyarakat ${ }^{1,2,3}$.

Berdasarkan laporan UNAIDS, sampai dengan Juni 2014 secara global diestimasi 13,6 juta orang yang hidup dengan HIV telah mendapat terapi ARV. Di Indonesia, dilaporkan sampai dengan September 2014 proporsi orang dengan HIV/AIDS (ODHA) yang mendapat terapi ARV adalah sebesar $54,3 \%{ }^{4}$.

Prinsip pemberian ARV adalah harus menggunakan 3 jenis obat yang ketiganya harus terserap dan berada dalam dosis terapeutik dalam darah, dikenal dengan highly active antiretroviral therapy (HAART). Istilah HAART sering disingkat menjadi antiretroviral therapy (ART) atau terapi ARV. Pemerintah menetapkan paduan yang digunakan dalam pengobatan ARV dengan berdasarkan pada 5 aspek yaitu efektivitas, efeksamping/toksisitas, interaksi obat, kepatuhan, dan harga obat ${ }^{1}$.

Antiretroviral (ARV) hanya dapat mengendalikan replikasi virus HIV, tidak dapat membunuh virus HIV. Walaupun ARV dapat membuat virus HIV tidak terdeteksi dalam darah, namun virus tersebut tetap ada pada beberapa bagian tubuh yang tidak dapat dicapai oleh ARV (sanctuary sites), sehingga tidak dapat dibunuh sepenuhnya dari tubuh. Virus ini muncul ketika terapi ARV gagal atau dihentikan'. Oleh karena itu, untuk menekan virus secara terus menerus, ARV harus terus diminum secara teratur, berkelanjutan dan tepat waktu selama seumur hidup ${ }^{5,10}$.

Untuk mencapai supresi virologis yang baik diperlukan tingkat kepatuhan terapi ARV yang sangat tinggi. WHO merekomendasikan kepatuhan minum ARV minimal $95 \%$ dari jumlah obat yang diresepkan/semua dosis harus dimunim, tidak boleh ada yang terlupakan, hal ini untuk mencapai supresi virus yang optimal. Risiko kegagalan terapi timbul jika pasien sering lupa minum obat. Kerjasama yang baik antara tenagakesehatan dengan pasien serta komunikasi dan suasana pengobatan yang konstruktif akan membantu pasien untuk patuh minum obat ${ }^{1,11}$.

Dalam terapi ARV, kepatuhan terhadap janji ambil obat juga merupakan hal yang penting, hal ini berkaitan dengan keberhasilan terapi ARV. Kepatuhan terhadap janji ambil obat (appointment keeping) adalah kepatuhan pasien untuk mengambil obat sesuai jadwal yang ditentukan. Kepatuhan terhadap kontrol/janji amil obat ini juga merupakan salah satu indikator yang digunakan WHO dalam kewaspadaan dini terhadap resistensi ARV (HIV Drug Resistance Early Warning Indicators) ${ }^{8}$.

Informasi mengenai gambaran kesintasan pasien HIV/AIDS berdasarkan kepatuhan berobat pasien HIV/AIDS belum banyak diteliti, khususnya di Indonesia, sehingga perlu dilakukan penelitian tentang gambaran kesintasan pasien HIV/AIDS berdasarkan ketidakpatuhan berobat (ketidakpatuhan minum obat dan ketidak patuhan terhadap janji ambil obat) di RSPI Prof. dr. Sulianti Saroso tahun 2010-2012.

\section{METODOLOGI}

Metode penelitian yang digunakan adalah penelitian deskriptif, yang kemudian akan dianalisis dengan analisis survival. Penelitian ini menggunakan populasi kohort dinamik (dynamic cohort), yaitu subyek diikuti tidak secara bersamaan pada awal study kemudian diikuti selama 3 tahun atau sampai terjadinya event. Penelitian ini dilakukan di Rumah Sakit Penyakit Infeksi (RSPI) Prof. Dr. Sulianti Saroso Jakarta. Waktu penelitian dilaksanakan pada bulan MeiJuni 2015.

Populasi studi pada penelitian ini adalah semua pasien HIV/AIDS di Rumah Sakit Penyakit Infeksi-Sulianti Saroso 
tahun 2010-April 2012 yang memenuhi kriteria inklusi dan eksklusi. Kriteria inklusi adalah pasien HIV berusia $\geq 15$ tahun saat didiagnosis dan yang mendapat terapi ARV minimal 12 bulan sejak awal minum ARV. Kriteria eksklusinya adalah wanita hamil dan pasien HIV/AIDS dengan catatan rekam medis pasien yang tidak lengkap.

Besar sampel minimal diperoleh dengan perhitungan besar sampel untuk pengujian hipotesis untuk beda 2 rate analisis kesintasan dengan $\mathrm{Cl}$ 95\% dan power $80 \%$, didapatkan 60 orang perkelompok.

Sumber data yang digunakan berasal dari rekam medik, monitoring ARV, ikhtisar perawatan dan dan ART (follow up), data farmasi. Pengumpulan data menggunakan form yang dikembangkan sendiri oleh peneliti yang terdiri dari variabel penelitian berupa nomor rekam medik, nama (inisial), tanggal kunjungan setiap bulan, jumlah pil sisa, dan kode adherence ARV. Penelitian ini telah lolos Ethical Clearance dari Komite Etik Rumah Sakit Penyakit Infeksi Prof. Dr. Sulianti Saroso Jakarta.

Variabel independen utama dalam penelitian ini ada 2, yaitu ketidakpatuhan minum obat dan ketidakpatuhan terhadap janji ambil obat. Ketidakpatuhan minum obat adalah ketidakpatuhan pasien HIV minimal sudah 12 bulan terapi ARV untuk mengkonsumsi obat ARV sesuai dosis yang ditentukan yang dinilai dari jumlah obat yang tidak diminum berdasarkan laporan pasien pada saat kunjungan (mengambil obat) ${ }^{8,12}$. Ketidakpatuhan ini dihitung berdasarkan jumlah bulan dimana pasien HIV/AIDS dikatakan patuh dibagi dengan jumlah bulan follow up selama 3 tahun atau sampai dengan terjadinya event. Pasien HIV/AIDS dikatakan patuh jika kepatuhan minum obatnya $\geq 95 \%$ atau pasien minum obat paling tidak $95 \%$ dari obat yang diberikan/diresepkan ${ }^{1,7,12}$.

Ketidakpatuhan terhadap janji ambil obat, yaitu ketidakpatuhan pasien HIV yang minimal sudah 12 bulan terapi ARV untuk mengambil obat ARV sesuai jadwal yang ditentukan ${ }^{8}$. Ketidakpatuhan ini dihitung berdasarkan kumulatif hari terlambat pasien HIV dalam menepati janji ambil obat sesuai waktu yang ditentukan sejak pertama kali pengambilan obat sampai dengan penelitian berakhir atau terjadinya event ${ }^{13}$.

Outcome dalam penelitian adalah waktu terjadinya kematian. Terjadinya kematian/kejadian meninggal dalam waktu pengamatan sampai tahun 2015. Kejadian meninggal dapat terjadi di RS, baik disebabkan karena penyakit AIDS atau penyakit lainnya yang disahkan oleh pihak RS. Kejadian meninggal juga dapat terjadi setelah pasien pulang dari $R S$ dan informasi tentang kematiannya diperoleh dari pernyataan keluarga terdekat pasien yang dihubungi oleh pihak RS melalui telepon, dengan cara menanyakan kondisi pasien. Pasien dikatakan sensor jika pasien hidup dalam masa pengamatan setelah pemberian ARV atau hilang dari pengamatan hingga akhir studi ${ }^{14}$.

\section{HASIL}

Tabel 1. Distribusi Frekuensi subyek penelitian berdasarkan ketidakpatuhan minum Obat, Ketidakpatuhan terhadap janji ambil obat dan variabel kovariat berdasarkan status kematian

\begin{tabular}{|c|c|c|c|c|c|c|c|c|}
\hline \multirow{2}{*}{ No. } & \multirow{2}{*}{ Variabel } & \multirow{2}{*}{ Kategori } & \multicolumn{2}{|c|}{ Event } & \multicolumn{2}{|c|}{ Sensor } & \multicolumn{2}{|c|}{ Total } \\
\hline & & & $\mathbf{N}$ & $\%$ & $\mathbf{n}$ & $\%$ & $\mathbf{n}$ & $\%$ \\
\hline \multirow[t]{2}{*}{1} & Ketidakpatuhan & Patuh & 12 & 15,6 & 65 & 84,4 & 77 & 100 \\
\hline & minum obat & Tidak patuh & 2 & 2,3 & 85 & 97,7 & 87 & 100 \\
\hline \multirow[t]{2}{*}{2.} & Ketidakpatuhan & Patuh & 9 & 11,4 & 70 & 88,6 & 79 & 100 \\
\hline & $\begin{array}{l}\text { terhadap janji } \\
\text { ambil obat }\end{array}$ & Tidak patuh & 5 & 5,9 & 80 & 94,1 & 85 & 100 \\
\hline
\end{tabular}


Berdasarkan tabel 1 didapatkan hasil distribusi frekuensi pasien HIV/AIDS berdasarkan variabel independen utama dan variabel kovariat berdasarkan event dan sensor. Dari 164 subyek penelitian yang diamati, terdapat $14(8,5 \%)$ pasien yang mengalami event (meninggal) dan $150(91,5 \%)$ orang yang hidup atau loss to follow up.

Berdasarkan ketidakpatuhan minum obat, yang mengalami event lebih tinggi pada kelompok yang tidak patuh, yaitu sebesar 11,4\%. Variabel kepatuhan minum obat ini menggunakan cut off point berdasarkan RoC, yaitu didapatkan kategori patuh minum obat $>88 \%$ dan tidak patuh minum obat $\leq 88 \%$, dengan nilai sensitifitas $85,7 \%$ dan spesifisitas $57,3 \%$. Berdasarkan ketidakpatuhan terhadap janji ambil obat, yang mengalami event lebih tinggi pada kelompok yang tidak patuh, yaitu sebesar $11,4 \%$. Variabel ketidakpatuhan terhadap janji ambil obat ini juga menggunakan RoC, yaitu didapatkan kategori patuh $\leq 12$ hari terlambat dan tidak patuh minum obat $>12$ hari terlambat, dengan nilai sensitifitas $71,4 \%$ dan spesifisitas $49,3 \%$.

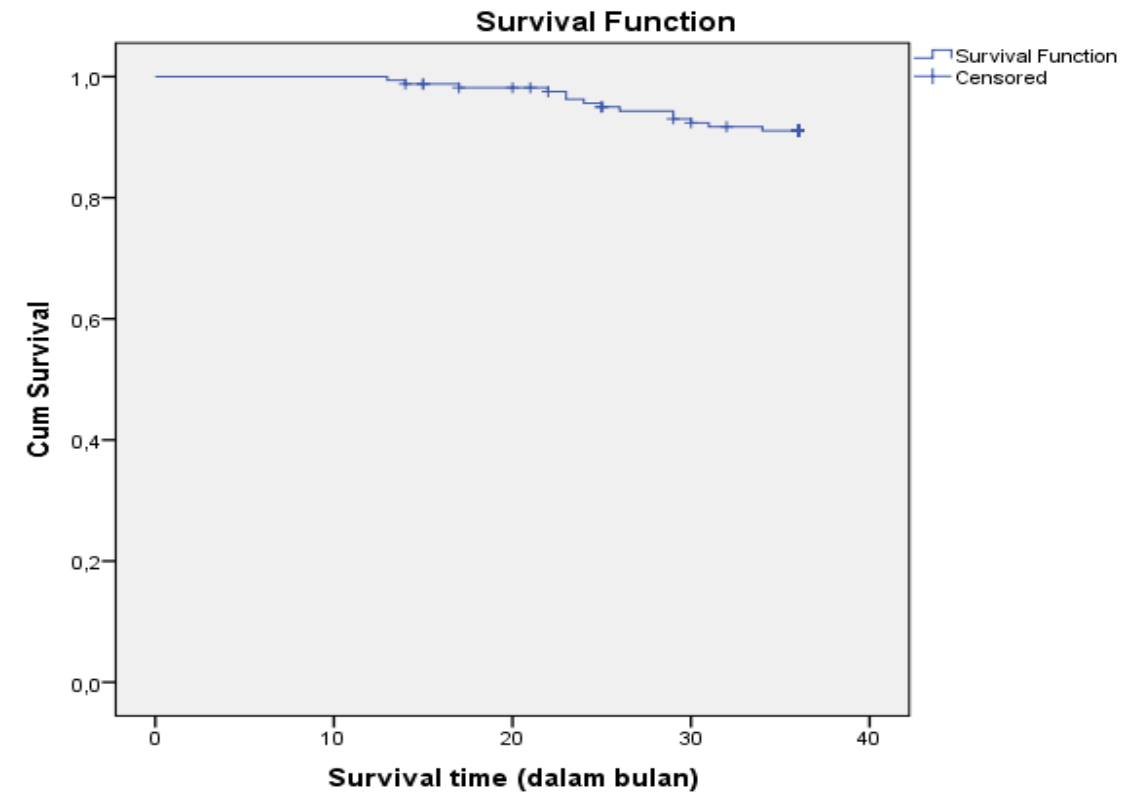

Gambar 2 Probabilitas Kumulatif Kesintasan 3 tahun Pasien HIV/AIDS di RSPI Prof. Dr. Sulianti Saroso Tahun 2010-2012
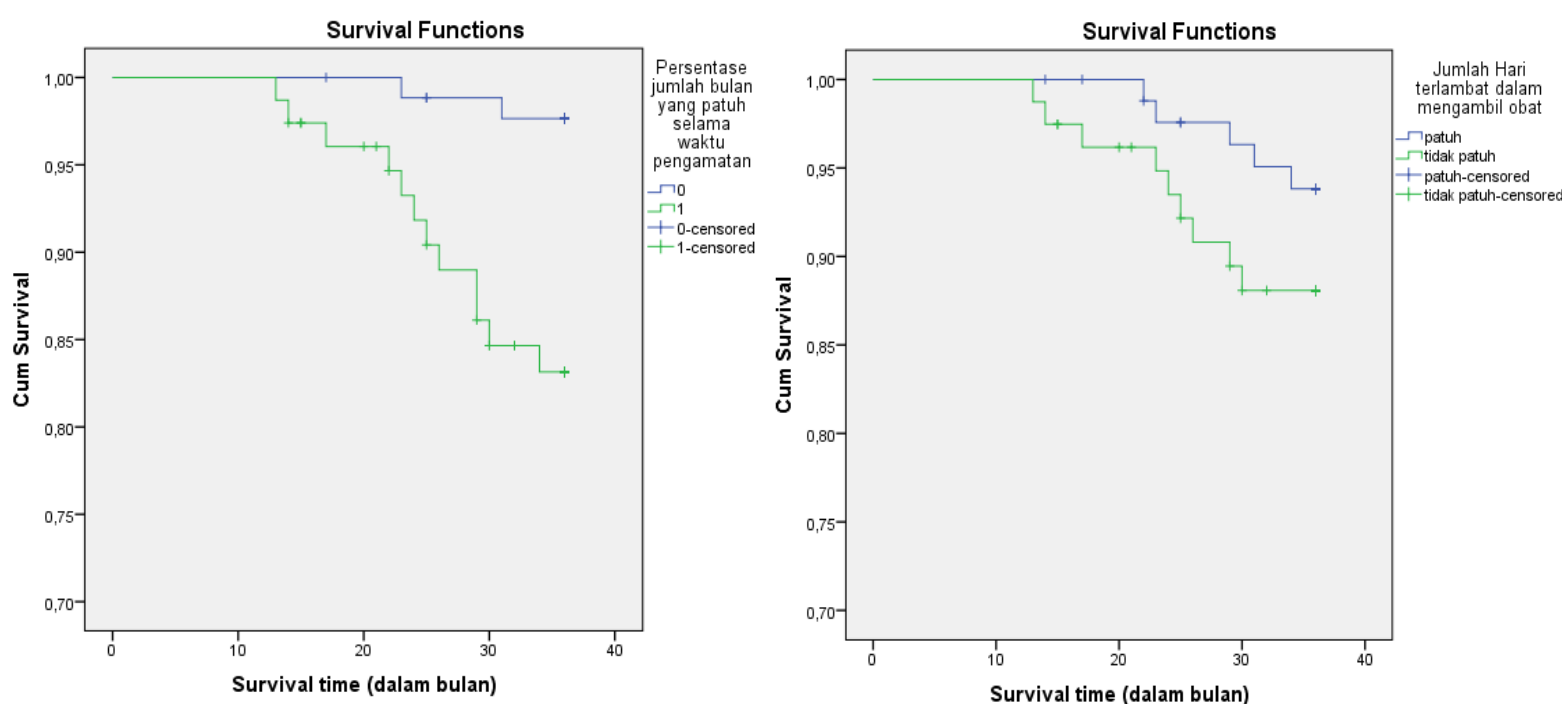

Gambar 3. Probabilitas Kumulatif Kesintasan 3 tahun Pasien HIV/AIDS Berdasarkan Ketidakpatuhan Minum Obat dan Ketidakpatuhan Janji Ambil Obat di RSPI Prof. Dr. Sulianti Saroso Tahun 2010-2012 
Tabel 2. Probabilitas Kesintasan 3 tahun Pasien HIV/AIDS Berdasarkan Ketidakpatuhan Minum Obat dan Janji Ambil Obat

\begin{tabular}{llccc}
\hline \multicolumn{1}{c}{ Variabel } & \multicolumn{1}{c}{ Kategori } & $\begin{array}{c}\text { Probabilitas } \\
\text { Kumulatif }\end{array}$ & $\begin{array}{c}\text { Mean } \\
\text { (bulan) }\end{array}$ & $\begin{array}{c}\text { Log Rank } \\
\text { Test }\end{array}$ \\
\hline Ketidakpatuhan terhadap & Tidak Patuh & 0,831 & 33,99 & 0,001 \\
Minum Obat & Patuh & 0,976 & 35,78 & \\
& & & & \\
Ketidakpatuhan Terhadap & Tidak Patuh & 0,881 & 34,32 & 0,183 \\
Janji Ambil Obat & Patuh & 0,938 & 35,47 & \\
& & & & \\
& &
\end{tabular}

${ }^{*}$ signifikan, nilai $p<0,05$

Tabel 3. Distribusi Ketidakpatuhan Janji Ambil Obat pada Pasien HIV/AIDS berdasarkan Ketidakpatuhan Minum Obat

\begin{tabular}{lcccc}
\hline \multirow{2}{*}{$\begin{array}{c}\text { Ketidakpatuhan terhadap Janji } \\
\text { Ambil Obat }\end{array}$} & \multicolumn{4}{c}{ Ketidakpatuhan Minum Obat } \\
\cline { 2 - 5 } & \multicolumn{2}{c}{ Tidak Patuh } & \multicolumn{3}{c}{ Patuh } \\
\cline { 2 - 5 } & $\mathbf{n}$ & $\%$ & $\mathbf{n}$ & $\%$ \\
\hline Tidak Patuh & 51 & 64,9 & 28 & 35,4 \\
Patuh & 26 & 30,6 & 59 & 69,4 \\
\hline
\end{tabular}

Berdasarkan gambar 2, didapatkan bahwa probabilitas survival kumulatif pasien HIV/AIDS. Pada tahun kedua (bulan ke-24) adalah 0,956 dan tahun ketiga (bulan ke-36) adalah 0,91.

Berdasarkan gambar 3 , terlihat plot survival pada yang tidak patuh minum obat dan tidak patuh ambil obat lebih besar mengalami penurunan seiring bartambahnya waktu. Hal ini menunjukkan bahwa survival pada kelompok yang patuh minum obat dan patuh ambil obat lebih tinggi daripada yang tidak patuh minum obat.

Berdasarkan tabel 2, diketahui probabilitas kesintasan 3 tahun pasien yang patuh minum obat lebih tinggi dibandingkan pada yang tidak patuh minum obat, yaitu 0,976 dan 0,831 . Hasil uji log rank test, didapatkan bahwa kesintasan kedua kelompok secara signifikan berbeda $(p<0,05)$. Berdasarkan ketidakpatuhan terhadap janji ambil obat, probabilitas kesintasan 3 tahun pasien yang patuh ambil obat juga lebih tinggi dibanding yang tidak patuh, yaitu 0,938 dan 0,881 . Hasil uji log rank test, didapatkan bahwa kesintasan kedua kelompok tidak berbeda secara statistik ( $p$ $>0,05)$.

Berdasarkan tabel 3, didapatkan bahwa pada kelompok yang tidak patuh ambil obat lebih tinggi yang tidak patuh minum obat, yaitu sebesar $64,9 \%$ dan pada kelompok yang patu ambil obat lebih tinggi yang patuh minum obat, yaitu sebesar $69,4 \%$.

\section{PEMBAHASAN}

Dalam penelitian ini terdapat beberapa keterbatasan yang mempengaruhi validitas hasil seperti bias informasi dan kemungkinan kesalahan random dikarenakan jumlah sampel yang masih kurang. Keterbatasan penelitian retrospektif menggunakan data dari rekam medik yang diisi oleh pihak lain di masa lalu, kualitas pengukurannya tidak dapat dikontrol oleh peneliti sehingga kemungkinan terjadi ketidaklengkapan data, kesalahan pencatatan, atau data tidak sesuai dengan yang dibutuhkan peneliti. Selain itu, terdapat data pasien yang tidak lengkap (7,6\%) dan tidak tersedia $(10,97 \%)$, sehingga tidak dapat diikutkan kedalam penelitian.

Bias informasi/misklasifikasi eksposure yang mungkin terjadi pada penelitian ini adalah informasi mengenai kepatuhan minum obat. Informasi kepatuhan minum obat didapat dari self reported atau dari pengakuan pasien terhadap jumlah pil yang tidak diminum. Pengakuan pasien dapat dipengaruhi oleh faktor lain yang menyebabkan pasien melaporkan tidak sesuai dengan yang terjadi. Misalnya, supaya pasien dibilang patuh atau tidak ingin diingatkan perawat/petugas farmasi 
atau juga karena terjadinya recall bias, dimana pasien lupa berapa kali tidak minum obat atau berapa pil yang tidk diminum dalam 1 bulan tersebut. Namun bias informasi ini terjadi pada kedua kelompok, baik patuh maupun tidak patuh, dimana hal ini dapat menyebabkan bias yang bersifat nondifferential.

Pada penelitian ini didapatkan probabilitas survival kumulatif pasien HIV/AIDS di RSPI Prof dr. Sulianti Saroso pada tahun kedua (bulan ke-24) adalah 95,6\% dan tahun ketiga (bulan ke-36) adalah 91\%. Probabilitas kesintasan dalam penelitian ini lebih tinggi dibandingkan probabilitas kesintasan 3 tahun pada penelitian di RSPI Prof. Dr. Sulianti Saroso sebelumnya, yaitu $82,81 \%$ pada tahun kedua dan $79,26 \%$ pada tahun ketiga ${ }^{15}$ dan pada penelitian di RSUD Arifin Rachmad Pekanbaru, yaitu $80 \%$ dan $78,5 \%{ }^{16}$.

Probabilitas pada penelitian ini lebih tinggi dikarenakan hanya mengikutkan pasien HIV/AIDS yang sudah mendapat terapi ARV 1 tahun, sedangkan pada penelitian Meilani tahun 2014 tersebut adalah semua pasien yang mendapat terapi ARV dan pada penelitian Triana, D., tahun 2013 adalah semua pasien HIV/AIDS, baik yang mendapat maupun yang tidak terapi ARV. Kriteria eksklusi yang mendapat terapi kurang dari 1 tahun berarti mengeksklude kematian awal dalam terapi ARV, dimana berdasarkan penelitian sebelumnya, diketahui bahwa kematian pasien HIV yang mendapat terapi ARV paling banyak adalah pada 4 bulan pertama, sehingga kematian yang didapat pada penelitian ini akan lebih kecil dan probabilitas kesintasannya lebih besar 17,18

Pengukuran kepatuhan minum obat dalam penelitian ini sama dengan penelitian di Afrika Selatan, yaitu dengan menghitung persentase bulan yang patuh dibagi dengan jumlah bulan follow up, dengan kriteria inklusi pasien yang sudah minum ARV minimal 1 bulan. Pada penelitian ini, variabel kepatuhan minum obat menggunakan cut off point berdasarkan RoC, yaitu didapatkan kategori patuh minum obat $>88 \%$ dan tidak patuh minum obat $\leq 88 \%$, dengan nilai sensitifitas $85,7 \%$ dan spesifisitas $57,3 \%$.

Hasil analisis menunjukkan bahwa probabilitas kesintasan pasien HIV/AIDS yang patuh minum obat lebih tinggi, yaitu $97,6 \%$ dibanding yang tidak patuh minum obat, yaitu $83,1 \%$. Hasil penelitian ini sejalan dengan penelitian di India, yang menunjukkan bahwa kesintasan pasien HIV/AIDS pada yang patuh terhadap janji ambil obat lebih tinggi, yaitu $62,3 \%$ dibanding pada yang tidak patuh $(14,6 \%)^{19}$.

Hal ini juga sejalan dengan penelitian di Spanyol, yang menunjukkan bahwa kesintasan pasien HIV/AIDS yang patuh lebih tinggi dibandingkan dengan pasien yang tidak patuh. Hal ini dapat dilihat dari nilai Hazard Rate (HR) yang didapat, yaitu $=3,87 \quad(95 \% \mathrm{Cl}: 1,77-8,46)$ yang menunjukkan bahwa pasien HIV/AIDS yang tidak patuh terhadap terapi ARV berisiko 4 kali lebih tinggi mengalami kematian dibandingkan pasien yang patuh. Penilaian kepatuhan yang digunakan berdasarkan jumlah dosis yang tidak diminum dalam sebulan, yang dikategorikan menjadi patuh jika mengkonsumsi $\geq 90 \%$ dari dosis yang diberikan dalam 1 bulan ${ }^{6,20}$.

Ketidakpatuhan terhadap terapi ARV dapat menyebabkan kegagalan virologik, imunologik, respon klinis. Hal ini dikarenakan Antiretroviral (ARV) hanya dapat mengendalikan replikasi virus HIV, tidak dapat membunuh virus HIV. Oleh karena itu, untuk menekan virus secara terus menerus, ARV harus terus diminum secara teratur, berkelanjutan dan tepat waktu selama seumur hidup ${ }^{5,10}$.

Ketidakpatuhan minum obat dapat menyebabkan kegagalan terhadap penekanan replikasi virus HIV, sehingga meningkatkan kemungkinan bermutasinya virus HIV yang dapat menyebabkan resisten terhadap obat dan akhirnya dapat meningkatkan risiko kematian. Ketidakpatuhan minum obat juga menyebabkan kegagalan dalam mencegah kehancuran sistem selular imun sehingga menyebabkan CD4 turun dan munculnya infeksi oportunistik, dan akhirnya meningkatkan risiko kematian ${ }^{6}$.

Probabilitas kesintasan pasien HIV/AIDS berdasarkan ketidakpatuhan 
terhadap janji ambil obat juga menunjukkan hal yang sama, yaitu kesintasan pasien HIV/AIDS yang patuh ambil obat lebih tinggi, yaitu 93,8\% dibanding yang tidak patuh ambil obat, yaitu $88,1 \%$.

Variabel kepatuhan terhadap janji ambil obat diukur berdasarkan jumlah hari terlambat pasien HIV/AIDS sesuai dengan tanggal rencana kunjungan. Penentuan cut off pointnya juga menggunakan RoC, yaitu didapatkan kategori patuh $\leq 12$ hari terlambat dan tidak patuh minum obat $>12$ hari terlambat, dengan nilai sensitifitas $71,4 \%$ dan spesifisitas $49,3 \%$.

Kepatuhan terhadap janji ambil obat hanya dinilai 1 tahun pertama terapi ARV, hal ini diasumsikan dapat menggambarkan kepatuhan terhadap janji ambil obat selanjutnya. Pengukuran kepatuhan ini sama dengan penelitian Park, et al tahun 2006 di Korea Selatan. Pengukuran kepatuhan yang digunakan adalah jumlah hari terlambat selama 1 tahun. Kriteria inklusi dalam penelitian tersebut juga sama dengan penelitian ini, yaitu pasien HIV/AIDS yang sudah 1 tahun mendapatkan terapi ARV.

Hasil penelitian tersebut juga sejalan dengan penelitian ini, yaitu kesintasan pasien HIV/AIDS pada yang patuh terhadap janji ambil obat lebih tinggi dibanding pada yang tidak patuh. Hal ini dapat dilihat dari nilai Hazard Rate (HR) yang didapat. Jumlah hari terlambat pada penelitian tersebut dibagi menjadi 5 kategori, yaitu 0 hari, 1-29 hari, 30-59 hari, 60-119 hari dan $\geq 120$ hari, dengan nilai HR berturut-turut $1,01 \quad(95 \% \mathrm{Cl}$ : $0,33-$ $3,10), 5,75$ (2,02-16,37), 6,91 (2,39-19,95) dan 10,17 (4,46-23,20) dengan reference adalah jumlah hari terlambat $=0$ (tidak pernah terlambat), yang artinya bahwa risiko kematian pada pasien HIV/AIDS yang tidak patuh ambil obat lebih tinggi dibanding pasien yang patuh. Atau dapat dikatakan bahwa kesintasan pasien yang HIV/AIDS yang patuh lebih tinggi dibanding yang tidak patuh ${ }^{13}$.

Hasil penelitian ini juga sejalan dengan penelitian di Birmingham tahun 2008, yang menunjukkan bahwa pasien HIV/AIDS yang tidak patuh terhadap janji ambil obat dalam 1 tahun pertama terapi ARV berisiko 2,9 kali lebih tinggi mengalami kematian dibandingkan dengan pasien yang patuh ( $\mathrm{HR}=2,9$; $95 \% \mathrm{Cl}: 2,38-6,56)$. Hal ini menunjukkan juga bahwa pasien yang patuh terhadap janji memiliki kesintasan lebih tinggi dibanding pasien yang tidak patuh ${ }^{21}$.

Ketidakpatuhan terhadap janji ambil obat selama 1 tahun pertama menggambarkan perilaku kesehatan yang berhubungan dengan peningkatan risiko kematian. Ketidakpatuhan terhadap janji ambil obat pada 1 tahun pertama juga juga akan menunjukkan ketidakpatuhan terhadap janji ambil obat selanjutnya dan menunjukkan ketidakpatuhan minum obat, sehingga meningkatkan risiko kematian. Oleh karena itu, ketidakpatuhan terhadap janji ambil obat, dapat dijadikan penanda dalam mengidentifikasi pasien HIV/AIDS yang berisiko memiliki kondisi kesehatan

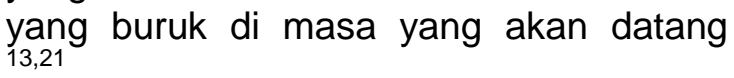

Selain itu, didapatkan juga bahwa pada pasien HIV/AIDS yang tidak patuh minum obat, yang tidak patuh ambil obat berisiko 4,5 kali lebih tinggi/cepat mengalami kematian dibandingkan pasien HIV/AIDS yang patuh ambil obat, setelah dikontrol variabel CD4 awal, jenis kelamin, PPK, faktor risiko penularan, stadium klinis awal, infeksi oportunistik, dan umur ( aHR $=4,517 ; 95 \% \mathrm{Cl}: 0,729-27,987)$.

Hal ini menunjukkan bahwa pasien HIV/AIDS yang tidak patuh ambil obat akan cenderung tidak patuh minum obat (lihat tabel 3), dan menunjukkan risiko yang lebih tinggi mengalami kematian dibanding pasien HIV/AIDS yang patuh ambil obat. Atau dapat dikatakan bahwa ketidakpatuhan terhadap janji ambil obat merupakan prediktor penting terhadap ketidakpatuhan minum obat dan risiko kematian pasien HIV/AIDS.

\section{KESIMPULAN}

Probabilitas survival kumulatif pasien HIV/AIDS di RSPI Prof. Dr. Sulianti Saroso tahun kedua (bulan ke-24) adalah 0,956 dan tahun ketiga (bulan ke-36) adalah 0,91 . Probabilitas kesintasan 3 tahun pasien HIV/AIDS di RSPI Prof. Dr. Sulianti Saroso pada kelompok yang patuh minum obat lebih tinggi daripada yang tidak patuh minum obat, yaitu $97,6 \%$ 
da $83,1 \%$. Probabilitas kesintasan 3 tahun pasien HIV/AIDS di RSPI Prof. Dr. Sulianti Saroso pada kelompok yang patuh terhadap janji ambil obat lebih tinggi daripada yang tidak patuh, $93,8 \%$ dan $88,1 \%$.

Pasien HIV/AIDS yang tidak patuh ambil obat akan cenderung tidak patuh minum obat, dan menunjukkan risiko yang lebih tinggi mengalami kematian dibanding pasien HIV/AIDS yang patuh ambil obat.

\section{SARAN}

Perlu dilakukan monitoring cakupan kepatuhan minum obat pasien HIV/AIDS secara berkala, misal sekali 6 bulan atau 1 tahun. Pada penelitiain ini didapatkan bahwa pasien HIV/AIDS yang persentase jumlah bulan yang patuh (adherence $\geq 95 \%$ ) selama masa pengamatan sampai dengan 3 tahun $<88 \%$ memiliki kesintasan yang lebih rendah dan berisiko lebih tinggi/cepat mengalami kematian. Selain itu, jumlah hari terlambat dalam 1 tahun terapi ARV juga dapat dijadikan indikator untuk memprediksi kepatuhan atau kondisi kesehatan pasien HIV/AIDS di waktu yang akan datang. Namun, hal ini masih perlu dilakukan penelitian lebih lanjut dengan sampel yang lebih besar.

Untuk penelitian lanjutan, perlu dilakukan penelitian tentang pengaruh ketidakpatuhan terapi ARV dengan resistensi obat atau kegagalan berobat (baik itu berdasarkan penurunan viral load aatau penurunan CD4 hitung), agar dapat menjadi kewaspadaan dini yang lebih awal dibandingkan kejadian kematian.

\section{DAFTAR PUSTAKA}

1. Kemkes, Ditjen PP\&PL. Pedoman Nasional Tatalaksana Klinis Infeksi HIV dan Terapi Antiretroviral Pada Orang Dewasa. Jakarta; 2011.

2. Mills EJ, Bakanda C, Birungi J, Chan K, Ford N, Cooper CL, et al. Life Expectancy of Persons Receiving Combination Antiretroviral Therapy in Low-Income Countries: A Cohort Analysis From Uganda. Ann Intern Med. 2011 Aug 16;155(4):209-16.
3. Walensky RP, Paltiel AD, Losina E, Mercincavage LM, Schackman BR, Sax PE, et al. The survival benefits of AIDS treatment in the United States. J Infect Dis. 2006;194(1):119.

4. Kemenkes RI, Ditjen PP\&PL. Laporan Perkembangan HIV-AIDS Triwulan III Tahun 2014. 2014.

5. Beck EJ, Holland L-M. The HIV pandemic: local and global implications [Internet]. Oxford University Press; 2006 [cited 2015 Mar 24]. Available from: https://www.google.com/books?hl=en $\& \mid r=\& i d=L r y W g n T g p 2 c C \& o i=f n d \& p g=$ PR5\&dq=the+hiv+pandemic+local+a nd + global+\&ots $=$ dj30Y3FPPU $\&$ sig $=j$ hq48C_nTteRKcOPULLxd4g-BUE

6. Maggiolo $F$, Airoldi M, Kleinloog HD, Callegaro A, Ravasio V, Arici C, et al. Effect of adherence to HAART on virologic outcome and on the selection of resistance-conferring mutations in NNRTI- or Pl-treated patients. HIV Clin Trials. 2007 Oct;8(5):282-92.

7. Hardon A, Davey S, Gerrits T, Hodgkin $\mathrm{C}$, Irunde $\mathrm{H}$, Kgatlwane J, et al. From access to adherence: the challenges of antiretroviral treatment [Internet]. World Health Organization; 2006 [cited 2015 Mar 24]. Available from: http://wwwlive.who.int/entity/ medicines/publications/challenges_ar vtreatment15Aug2006.pdf

8. WHO. HIV Drug Resistance Early Warning Indicators. World Health Organization Indicators to Monitor HIV Drug Resistance Prevention at Antiretroviral Treatment Sites. WHO; 2010.

9. Ministry of Health, Kenya. Adherence to Antiretroviral Therapy in Adults. Kenya: Population Council; 2004.

10. Nursalam, Kurniawati ND. Asuhan Keperawatan pd Pasien Terinfeksi HIV/AIDS. Jakarta: Penerbit Salemba; 2007.

11. WHO. Consolidated guidelines on the use of antiretroviral drugs for treating and preventing HIV infection [Internet]. WHO. 2013 [cited 2015 Apr 4]. Available from: http://www. 
who.int/hiv/pub/guidelines/arv2013/e $\mathrm{n} /$

12. Lima VD, Harrigan R, Murray $M$, Moore DM, Wood E, Hogg RS, et al. Differential impact of adherence on long-term treatment response among naive HIV-infected individuals. Aids. 2008;22(17):2371-80.

13. Park WB, Choe PG, Kim S-H, Jo JH, Bang $\mathrm{JH}$, Kim $\mathrm{HB}$, et al. One-year adherence to clinic visits after highly active antiretroviral therapy: a predictor of clinical progress in HIV patients. J Intern Med. 2007 Mar;261(3):268-75.

14. Kleinbaum DG, Klein M. Survival analysis. A self-learning approach. Springer N Y USA. 2005;

15. Meilani, M. Pengaruh Koinfeksi Tuberkulosis Terhadap Kesintasan Tiga Tahun Pasien HIV/AIDS Yang Mendapat Terapi ARV Di Rumah Sakit Penyakit Infeksi Prof. Dr. Sulianti Saroso [Tesis]. [Depok]: FKM UI; 2014.

16. Triana, D. Pengaruh Terapi Antiretroviral Terhadap Survival Pasien dengan HIV/AIDS di Rumah Sakit Arifin Achmad Pekanbaru Propinsi Riau sampai dengan Juni 2013 [Tesis]. [Depok]: FKM UI; 2013.

17. Collaboration AT in LIC (ART-L, Collaboration AC, others. Mortality of HIV-1-infected patients in the first year of antiretroviral therapy: comparison between low-income and high-income countries. The Lancet. 2006;367(9513):817-24.

18. Mermin J, Were W, Ekwaru JP, Moore D, Downing R, Behumbiize $P$, et al. Mortality in HIV-infected Ugandan adults receiving antiretroviral treatment and survival of their HIV-uninfected children: a prospective cohort study. The Lancet. 2008 Mar;371(9614):752-9.

19. Rai S, Mahapatra B, Sircar S, Raj PY, Venkatesh S, Shaukat M, et al. Adherence to Antiretroviral Therapy and Its Effect on Survival of HIVInfected Individuals in Jharkhand, India. PLoS ONE. 2013 Jun;8(6):1-7.

20. de Olalla PG, Knobel H, Carmona A, Guelar A, López-Colomés JL, Caylà JA. Impact of Adherence and Highly
Active Antiretroviral Therapy on Survival in HIV-Infected Patients: JAIDS J Acquir Immune Defic Syndr. 2002 May;30(1):105-10.

21. Mugavero MJ, Lin $\mathrm{H}-\mathrm{Y}$, Willig $\mathrm{JH}$, Westfall AO, Ulett KB, Routman JS, et al. Missed visits and mortality among patients establishing initial outpatient HIV treatment. Clin Infect Dis. 2009;48(2):248-56. 